\title{
Heat Shock Proteins and Disease Control in Aquatic Organisms
}

\section{Yeong Yik Sung ${ }^{1,2 *}$ and Thomas H MacRae}

${ }^{1}$ Department of Fisheries and Aquaculture, Faculty of Agrotechnology and Food Science, Universiti Malaysia Terengganu (UMT), 21030, Kuala Terengganu, Malaysia. ${ }^{2}$ Institute of Marine Biotechnology, Universiti Malaysia Terengganu (UMT), 21030, Kuala Terengganu, Malaysia.

${ }^{3}$ Department of Biology, Dalhousie University, Halifax, NS, B3H 4R2, Canada.

\begin{abstract}
Four families of heat shock proteins (Hsps), including the small heat shock proteins (sHsps), Hsp70, Hsp90 and Hsp60, are synthesized under normal physiological conditions and in response to stress. sHsps protect proteins from irreversible denaturation independently of ATP. The remaining ATP-responsive Hsps fold nascent proteins, shield proteins from irreversible denaturation during stress and aid protein refolding. Several observations indicate that Hsps contribute to disease resistance in aquatic organisms, the first being that these proteins are produced in finfish, shellfish and bivalves upon infection with viral and bacterial pathogens. Induction of Hsp synthesis by heat shock and incubation with chemicals such as Pro-Tex ${ }^{\otimes}$ boosts resistance to pathogens, as does administration of exogenous Hsps to host organisms. The extent of Hsp accumulation and the increase in disease tolerance are generally correlated with one another. Not only do Hsps protect against pathogens by functioning as molecular chaperones, but they are thought to mediate humoral and cellular innate immune responses. Hsp70 is highly immunogenic and serves as a ligand for Toll-like receptors. Hsps elicit cytokine production and they deliver peptides to antigen presenting cells via major histocompatibility complexes (MHC). Vaccines have been produced for use in aquaculture by employing Hsps, either alone or fused to antigens obtained from pathogens. Hsps offer several advantages over current methods for the treatment of disease in commercially important organisms and they are being increasingly exploited as their roles in protein chaperoning and immune modulation are better understood.
\end{abstract}

Keywords: Heat shock proteins; Molecular chaperone; Innate immunity; Disease; Vaccine; Aquatic organisms; Aquaculture

\section{Introduction}

Families of heat shock proteins (Hsps), otherwise known as stress proteins or molecular chaperones, consist of conserved molecules found in all organisms [1,2]. The expression of genes encoding Hsps is either constitutive or induced by stress and their products are essential for cell survival $[3,4]$. Under normal conditions Hsps mediate nascent protein folding and assembly, translocate proteins through membranes into organelles such as mitochondria, and assist in the degradation of structurally aberrant proteins. Hsps, often when functioning cooperatively with one another, prevent the irreversible denaturation of proteins exposed to physiological stressors such as heat, toxins and disease, thereby facilitating protein refolding and protecting cells from damage.

The Hsp70 family is the best studied group of Hsps in aquatic organisms, with interest centred on thermotolerance [5-7]. Hsp70 accretion is important in cross-protection where an organism acquires enhanced tolerance to a specific stress following an initial transient, but different, stress [2]. Hsp70 serves as a potential bioindicator of environmental perturbation because it is induced in aquatic organisms during exposure to temperature change, salinity variation, handling, toxins and other stresses [8,9]. Results from such monitoring must however, be interpreted carefully because Hsp gene expression and protein accumulation in test organisms respond to many environmental variables [10]. The Hsp reaction to stress was originally considered to be of short duration, but Hsps are now thought to have a longer term role by modulating the immune system [9]. As part of immune management, Hsp70 is released into extracellular compartments and influences the major histocompatibility complex (MHC)-dependent uptake of peptides by antigen-presenting cells, while at the same time functioning as an endogenous "danger signal", alerting the immune system to cell and tissue injury [11,12]. Hsp70 binds pathogen-associated molecular pattern (PAMP) molecules and modulates PAMP-induced Toll-like receptor (TLR) signalling $[1,13]$, activities crucial for stimulation of innate immunity and elimination of pathogens.

Modulation of innate and adaptive immune systems by Hsp70 is under study in organisms used for aquaculture [2]. Endogenous Hsp70 increases significantly subsequent to bacterial and viral infection of fin-fish and shrimp, protecting proteins by way of their chaperone activity during the stress of infection and suggesting linkage with the immune response $[9,14,15]$. Control of disease caused by vibriosis in the crustacean Artemia franciscana is achieved by employing non-lethal heat shock to boost endogenous Hsp70 [16,17] and by feeding the organism with bacteria enriched in DnaK, the prokaryotic equivalent of Hsp70 [18,19]. Platyfish are protected against Yersinia rukeri by injecting them with bacterial Hsps, an effect enhanced by non-lethal heat shock [20]. Application of Hsp stimulants such as Tex-OE ${ }^{\oplus}$, a patented extract of the prickly pear cactus Opuntia ficus indica that non-traumatically enhances stress protein synthesis in fish and shrimp, is useful against several bacterial and viral diseases [9]. Because microbial Hsp60 (GroEL) and Hsp70 (DnaK) are frequently major pathogen-derived antigens that invoke high antibody response, they have the potential to function as highly specific potent vaccines against harmful biotic agents $[21,22]$.

The structures and mechanisms of action of four major Hsp

*Corresponding author: Dr. Yeong Yik Sung, Department of Fisheries and Aquaculture, Faculty of Agrotechnology and Food Science, Universiti Malaysia Terengganu (UMT), 21030, Kuala Terengganu, Malaysia, Tel: +609-6683639; Fax: +609-6683434; E-mail: yeong@umt.edu.my

Received November 02, 2011; Accepted December 13, 2011; Published December 22, 2011

Citation: Sung YY, MacRae TH (2011) Heat Shock Proteins and Disease Contro in Aquatic Organisms. J Aquac Res Development S2:006. doi:10.4172/2155-9546. S2-006

Copyright: $(2011$ Sung YY, et al.This is an open-access article distributed under the terms of the Creative Commons Attribution License, which permits unrestricted use, distribution, and reproduction in any medium, provided the original author and source are credited. 
families produced by aquatic organisms are presented in this review. The synthesis of Hsps upon exposure to pathogens and the use of Hsps for disease control during aquaculture are considered. Exploiting Hsps for prevention and treatment of infections in commercially cultured aquatic organisms is important because it offers an alternative to the utilization of antibiotics and therapeutic drugs, methods with serious consequences for the environment and consumers, especially when used indiscriminately.

\section{The Structure and Function of Hsps}

Hsp families, named according to molecular mass $(\mathrm{kDa})$, amino acid sequence and function, include the small heat shock proteins (sHsps), Hsp60, Hsp70 and Hsp90. The synthesis of Hsps, both those that are expressed constitutively [heat shock cognates (Hscs)] and more commonly those that are not, are induced upon protein denaturation caused by thermal shock, heavy metals, free radicals, desiccation, microbial infection and other stressors. Hsps are molecular chaperones, aiding nascent polypeptide folding and oligomerization, protecting proteins from irreversible denaturation, re-folding or degrading damaged proteins, translocating proteins into membrane-bound cell compartments and contributing to disease resistance. The Hsp family of primary interest for disease control during aquaculture is Hsp70 but the sHsps, Hsp90 and Hsp60, as well as the co-chaperone Hsp40, appear to ameliorate infection by pathogens. The sHsps provide oligomeric platforms for the ATP-independent binding of structurally perturbed proteins, preventing their irreversible denaturation when cells are stressed. Hsp90, Hsp70 and Hsp60 are stress induced and they have the ability to protect proteins from irreversible denaturation. However, the major function of these chaperone families is to bind and fold nascent proteins through ATP-driven allosteric rearrangement, although the molecular structure and mechanism of action of each chaperone differ. The Hsps function cooperatively by forming intracellular networks of chaperones, co-chaperones and accessory proteins.

sHsp monomers, consisting of a conserved $a$-crystallin domain flanked by an amino-terminal sequence and a carboxyl-terminal extension $[4,23,24]$, assemble into oligomers [25-27]. The $a$-crystallin domain contributes to dimerization of monomers and substrate binding, activities that depend on the amino- and carboxyl- terminal regions for greatest efficiency [23,24,27-29]. sHsp oligomers either disassemble or undergo structural rearrangement during stress, increasing surface hydrophobicity and enhancing reaction with substrate proteins [24,30-32]. Proteins released from sHsps when stress passes either refold spontaneously or with the assistance of an ATP-dependent Hsp such as Hsp70 [33,34]. The primary role of sHsps during exposure to stress, including infection, is to protect proteins from irreversible denaturation (Table 1).

Hsp70 mediates the ATP-dependent folding of nascent proteins and the refolding of partially denatured proteins. Hsp70 has a conserved amino-terminal ATP binding/hydrolysis domain (NBD) connected by a hydrophobic flexible linker to a variable, carboxyl-terminal substrate binding domain (SBD) capped by a lid structure of unknown function [35,36]. Interaction with substrate and ATP, followed by nucleotide hydrolysis, promotes allosteric changes in the NBD and SBD, strengthening attachment of substrate to the chaperone and promoting folding [36-38]. ATP then replaces ADP, an action supported by cochaperone nucleotide exchange factors such as Bag1 [39,40], and the substrate is released from Hsp70. Members of the J-domain-containing Hsp40 co-chaperone family shuttle substrate proteins to Hsp70 and improve ATP hydrolysis [40-42]. Intracellular accumulation of Hsp70 protects against protein damage upon viral and bacterial challenge. Moreover, the mechanistic properties of Hsp70 permit binding, transport and release of peptides/proteins that stimulate the immune response and $\mathrm{Hsp} 70$ is thought to have this function [11].

Hsp90, an ATP-dependent dimer produced abundantly by cells under normal physiological conditions or induced by stress, is composed of monomers with three domains. The amino-terminal domain houses a nucleotide binding and hydrolysis site, the middle region interacts with substrates and co-chaperones, and the carboxylterminus, possessing a MEEVD motif for binding co-chaperones with tetratricopeptide repeats, governs constitutive dimerization [43]. The Hsp90 dimer assumes an open, substrate recognition configuration when monomers are connected only by the carboxyltermini. The hydrolysis of ATP compacts Hsp90 structure and aminoterminals dimerize, followed by substrate folding and release. Hsp90 combines with many different substrates including those undergoing denaturation [44,45]. Additionally, Hsp90 regulates cell activity through interaction with kinases and steroid hormone receptors [46] and by degrading proteins [47]. Hsp90 forms complexes with proteins late in folding some of which are associated with Hsp70/Hsp40 and are presented to Hsp90 by the co-chaperone Hsp70/Hsp90 organizing protein (Hop) [47-49]. Hop inhibits Hsp90 ATPase and keeps this Hsp in the open state $[47,50]$. Other co-chaperones such as p23 and Aha1 fine-tune Hsp90 interaction with chaperones and substrates [49].

Hsp60 (chaperonin, TRiC, CCT), the most structurally complex Hsp, is composed of two rings positioned back-to-back, each constructed with eight to nine different but related ATP-hydrolyzing monomers composed of three domains [51,52]. The apical domain reacts with substrate and it is topped by a built-in lid that confines client proteins within the ring cavities where folding occurs $[53,54]$. The intermediate region connects the Hsp60 apical and equatorial domains, the latter possessing inter- and intra-ring contacts and the ATP hydrolysis site [55,56]. Substrates often bind Hsp60 late in folding and they are released upon ATP hydrolysis and dissociation of ADP + Pi. Hsp60 associates with numerous different substrates via hydrophobic, polar and charged amino acid residues and the cytoskeleton proteins actin and tubulin depend on Hsp60 for correct folding [52,56-58]. Hsp60 has the ability to refold proteins denatured during infection and it may interact with peptides and proteins involved in the invertebrate immune response.

\section{Aquatic Organisms Respond to Disease by Altering Hsp Synthesis}

A relationship between Hsps and fish disease is implied by the strong induction of Hsp90 during an in vitro challenge of the Chinook salmon embryo cell line CHSE-214 with infectious hematopoietic necrosis virus (IHNV) $[8,59,60]$. In other examples of virus induced Hsp synthesis in fish Hsp90 increases when the orange-spotted grouper Epinephelus coioides encounters nodavirus [61] and exposure to UVinactivated turbot rhabdovirus (SMRV) up-regulates the expression of three Hsp40 genes in embryonic cell lines from the olive flounder Paralichthys olivaceus with marked stimulation of PoHsp40A4 and weaker production of PoHsp40B6 and PoHsp40B11 [62]. Infection of Coho salmon with Renibacterium salmoninarum, the causative agent of bacterial kidney disease, boosts Hsp70 in liver and kidney [63]. Hsp70 is augmented in rainbow trout after acute Vibrio anguillarum challenge [64], as is the case for sea bream, where hepatic Hsp70 peaks $36 \mathrm{~h}$ postinfection with live $V$. alginolyticus, although Hsp60 and Hsp90 are unchanged [65]. The mechanisms regulating piscine Hsp synthesis 
Citation: Sung YY, MacRae TH (2011) Heat Shock Proteins and Disease Control in Aquatic Organisms. J Aquac Res Development S2:006. doi:10.4172/2155-9546.S2-006

Page 3 of 10

\begin{tabular}{|c|c|c|}
\hline Hsp Familya & Hsp Structure and Function & References \\
\hline sHsps & $\begin{array}{l}\text { Multimeric complexes composed of monomers containing an amino-termial region, an a-crystallin domain and a carboxyl- } \\
\text { extension; the domains cooperate in oligomerization and substrate binding. } \\
\text { Prevent stress-induced irreversible protein } \\
\text { denaturation; inhibit apoptosis; ATP independent. }\end{array}$ & {$[4,23,24,26,27,32]$} \\
\hline Hsp70 & $\begin{array}{l}\text { Monomeric protein with a conserved ATP binding /hydrolysis site in the amino-terminus, a linker region and a variable } \\
\text { carboxyl substrate-binding domain. } \\
\text { Binds and folds nascent and denaturing proteins; protects against stresses such as bacterial infection. }\end{array}$ & {$[35,36,38,40]$} \\
\hline Hsp90 & $\begin{array}{l}\text { Dimeric protein; each monomer has an amino-terminal domain that hydrolyzes ATP, a substrate-binding middle domain } \\
\text { and a carboxyl-domain that interacts with co-chaperones. } \\
\text { Folds nascent and denaturing proteins; interacts with kinases and other regulatory molecules; protein degradation. }\end{array}$ & {$[43-46,49]$} \\
\hline $\begin{array}{l}\text { Hsp60 (chaperonin, } \\
\text { TRiC, CCT) }\end{array}$ & $\begin{array}{l}\text { Two back-to-back rings of eight to nine subunits each with an apical capped domain that binds substrate, an equatorial } \\
\text { region with an ATP hydrolysis site and a linking domain. } \\
\text { Binds substrates via hydrophobic, polar and charged residues; required by actin and tubulin for folding. }\end{array}$ & {$[51,52,54-56,58]$} \\
\hline
\end{tabular}

aThe Hsps are described separately but they function as co-operative networks to maintain protein homeostasis within cells, either during normal growth or upon exposure to stress such as heat, salinity, toxins and infection.

Table 1: The structure and function of Hsps involved in diseases of aquatic organisms

during disease are unknown but are likely to be similar to other types of stress where transcription is regulated by heat shock factor (HSF) recognition of up-stream heat shock elements (HSEs), a process promoted by protein denaturation. That is, when cells are damaged as the result of microbial infection, protein perturbation occurs, either within cells or on their surfaces [9]. The resulting Hsps protect against irreversible damage of proteins and/or assist in their repair.

Exposure to viral pathogens up-regulates Hsps in shellfish (Table 2). Hepatopancreas Hsp70 transcripts increase in the Chinese shrimp Fenneropenaeus chinensis after exposure to white spot syndrome virus (WSSV) [66], suggesting Hsp70 is a useful indicator of virus infection. WSSV triggers expression of Hsp70 in haemolymph of the mud crab Scylla serrata but reduces Hsp90, signifying functional differences between Hsp families in response to viral infection [67]. These studies suggest that Hsps influence the crustacean innate immune system. Quantitative PCR reveals a time-dependent increase in Hsp70 mRNA after challenge of the Japanese blue crab Portunus trituberculatus with $V$. alginolyticus, the main causative agent of emulsification disease in the swimming crab [68]. Hsp70 and Hsp90 transcripts are up-regulated in gills of the black tiger shrimp Penaeus monodon at 3, 12 and $24 \mathrm{~h}$ post-infection with V. harveyi [69]. However, Hsp90 is unchanged in hemocytes of $P$. monodon $24 \mathrm{~h}$ after infection and slightly reduced at 48 $\mathrm{h}[70]$, showing that Hsp90 expression is tissue specific. The P. monodon sHsp, Hsp21, is not induced concurrently with Hsp70 and Hsp90 but appears $24 \mathrm{~h}$ after bacterial contact. LvHsp60 mRNA is highly expressed in haemocytes, muscle, stomach, heart, hepatopancreas and gill tissue of the white leg shrimp Litopenaeus vannamei but less so in the intestine. Quantitative PCR and immunoprobing of western blots reveal respectively that LvHsp60 mRNA and protein are significantly up-regulated in the gills, hepatopancreas and haemocytes of L. vannamei after infection with Staphylococcus aureus and V. alginolyticus [71]. LvHsp70 transcripts are induced in haemocytes and the hepatopancreas of L. vannamei after bacterial challenge.

Several studies with bivalves focus on the transient synthesis of haemocyte sHsps in response to Vibrio challenge and suggest that they protect proteins undergoing denaturation upon pathogen exposure, although other functions are possible. The sHsp genes VpsHSP-1 and VpsHSP-2 are sequentially up-regulated in haemocytes of the Manila clam Venerupis philippinarum following $V$. anguillarum challenge [72].
The quantity of VpsHP-1 transcripts grows by 1.5 -fold and 9.9 -fold at 6 and 96 h post-infection respectively, whereas VpsHSP-2 mRNA multiplies 8.7 -fold $24 \mathrm{~h}$ post-infection but declines to 2.2 -fold after 96 h. mRNA transcripts encoding Tg-sHSP in haemocytes of the bloody clam Tegillarca granosa increase gradually from $1.5 \mathrm{~h}$ to $12 \mathrm{~h}$ after contact with $V$. parahaemolyticus and then decrease over the next few hours [73]. In yet another example, transcription of the gene encoding Hsp22 up-regulates in haemocytes of the Chikong scallop Chlamys farreri exposed to $V$. anguillarum, with maximum expression in $12 \mathrm{~h}$ followed by decline to the original level by $48 \mathrm{~h}$ [74]. The expression of co-chaperone Hsp40 in $V$. philippinarum haemocytes increases 6-fold relative to controls $24 \mathrm{~h}$ after incubation with $V$. anguillarum [75]. Hsp90 and Hsp83 rise in haemocytes of the soft-shell clam Mya arenaria $1 \mathrm{~h}$ after introduction to V. splendidus strain LGP32, followed by down-regulation thereafter [76].

MmeHsc71, a constitutive Hsp70 in the Asiatic hard clam Meretrix meretrix goes up 2-fold in the gill and hepatopancreas $24 \mathrm{~h}$ after infection by $V$. parahaemolyticus [77]. Hsp70 is expressed in the bay scallop Argopecten irradians after $V$. anguillarum challenge, with mRNA reaching maximum levels $8 \mathrm{~h}$ post-infection and lasting $16 \mathrm{~h}$ [78]. Not all bivalve Hsps are amplified during exposure to pathogenic microbes and as a case in point, mitochondrial Hsp60 is down-regulated in gills when the Mediterranean mussel Mytilus galloprovincialis comes in contact with Cylindrospermopsis raciborskii, a freshwater filamentous cyanobacterium, and with cylindrospermopsin (CYN) toxin [79]. Differential expression indicates Hsp functional diversity. Hsps may protect cell proteins from irreversible denaturation during diseaseinduced stress and/or assist in refolding once stress terminates. On a more speculative note, some Hsps may mediate the bivalve immune response.

\section{Increasing Hsps in Aquatic Organisms as an Approach to Disease Management}

Heat shock: The intensity of thermal stress required to boost Hsp expression in aquatic organisms varies across species and acclimation temperature. A frequently used protocol to stimulate Hsp expression entails a short non-lethal heat shock followed by incubation for several hours under non-stress conditions [2]. As noted previously, non-lethal heat stress at $37^{\circ} \mathrm{C}$ for $30 \mathrm{~min}$ followed by $6 \mathrm{~h}$ of recovery increases 
Citation: Sung YY, MacRae TH (2011) Heat Shock Proteins and Disease Control in Aquatic Organisms. J Aquac Res Development S2:006. doi:10.4172/2155-9546.S2-006

Page 4 of 10

\begin{tabular}{|c|c|c|c|c|}
\hline Host animal & Pathogen challenge & Tissue & Induced Hsp & References \\
\hline $\begin{array}{l}\text { Orange-spotted grouper Epi- } \\
\text { nephelus coioides }\end{array}$ & $\begin{array}{l}\text { Naturally infected with nodavirus (concentration not } \\
\text { available) }\end{array}$ & Cell line GF-1 from fin & Hsp90AB & [61] \\
\hline $\begin{array}{l}\text { Olive flounder } \\
\text { Paralichthys olivaceus }\end{array}$ & $\begin{array}{l}0.5 \mathrm{ml} \text { of } 1 \times 10^{9} \mathrm{UV} \text {-inactivated } \\
\text { SMRV }\end{array}$ & Embryonic cell lines & $\begin{array}{l}\text { PoHsp40A4 } \\
\text { PoHsp40B6 } \\
\text { PoHsp40B11 }\end{array}$ & [62] \\
\hline $\begin{array}{l}\text { Coho salmon } \\
\text { Oncorhynchus kisutch }\end{array}$ & $\begin{array}{l}0.1 \mathrm{ml} \text { of } 3 \times 10^{4} \text { cells } / \mathrm{ml} \\
\text { Renibacterium salmoninarum }\end{array}$ & Liver and kidney & Hsp70 & [63] \\
\hline $\begin{array}{l}\text { Rainbow trout } \\
\text { Oncorhynchus mykiss }\end{array}$ & $1 \times 10^{5} \mathrm{cfu} / \mathrm{fish} \mathrm{V}$. anguillarum & Liver and head kidney & Hsp70 & [64] \\
\hline $\begin{array}{l}\text { Sea bream } \\
\text { Sparus sarba }\end{array}$ & $4.9 \times 10^{4} \mathrm{cfu} / \mathrm{fish} V$. alginolyticus & Hepatic & Hsp70 & [65] \\
\hline $\begin{array}{l}\text { Chinese shrimp Fenneropenae- } \\
\text { us chinensis }\end{array}$ & $3 \mu \mathrm{l}$ of WSSV/shrimp, $6 \mathrm{~h}$ & Hepatopancrease & $\begin{array}{l}\text { Hsp70 } \\
\text { Hsp90 }\end{array}$ & [66] \\
\hline $\begin{array}{l}\text { Black tiger shrimp } \\
\text { Penaeus monodon }\end{array}$ & $\begin{array}{l}100 \mu \mathrm{l} / \mathrm{shrimp} \text { of } 2 \times 10^{8} \text { cells } / \mathrm{ml} \\
\text { heat-killed } V \text {. harveyi }\end{array}$ & Gill & $\begin{array}{l}\text { Hsp90 } \\
\text { Hsp70 } \\
\text { Hsp21 }\end{array}$ & [69] \\
\hline $\begin{array}{l}\text { White leg shrimp } \\
\text { Liptopenaeus vannamei }\end{array}$ & $\begin{array}{l}10 \mu \mathrm{l} / \mathrm{shrimp} \text { of } 1 \times 10^{7} \text { cells } / \mathrm{mL} \text { V. alginolyticus } \\
10 \mu \mathrm{l} \text { of } 1 \times 10^{7} \text { cells } / \mathrm{mL} \text { S. aureus }\end{array}$ & $\begin{array}{l}\text { Gills } \\
\text { Hepatopancreas } \\
\text { Haemocytes }\end{array}$ & $\begin{array}{l}\text { LvHsp60 } \\
\text { LvHsp70 }\end{array}$ & [71] \\
\hline $\begin{array}{l}\text { Mud crab } \\
\text { Scylla serrata }\end{array}$ & $0.2 \mathrm{~mL}$ of $1: 100$ diluted WSSV inoculums/crab & Haemolymph & Hsp70 & [67] \\
\hline $\begin{array}{l}\text { Japanese blue crab } \\
\text { Portunus trituberculatus }\end{array}$ & $\begin{array}{l}100 \mu \mathrm{l} / \mathrm{crab} \text { of } 1 \times 10^{6} \mathrm{CFU} / \mathrm{ml} \\
\text { V. alginolyticus, }\end{array}$ & $\begin{array}{l}\text { Gill } \\
\text { Haemocytes } \\
\text { Hepatopancreas } \\
\text { EyestalkW }\end{array}$ & Hsp70 & [68] \\
\hline $\begin{array}{l}\text { Manila clam } \\
\text { Venerupis philippinarum }\end{array}$ & $1 \times 10^{7} \mathrm{CFU} / \mathrm{mL} V$. anguillarum & Haemocytes & Hsp40 & [72] \\
\hline $\begin{array}{l}\text { Bloody clam } \\
\text { Tegillarca granosa }\end{array}$ & $20 \mu \mathrm{l}$ of $2 \times 10^{8} \mathrm{cfu} / \mathrm{ml} V$. parahaemolyticus, & Haemocytes & $\mathrm{sHsp}$ & [73] \\
\hline $\begin{array}{l}\text { Manila clam } \\
\text { Venerupis philippinarum }\end{array}$ & $1 \times 10^{7} \mathrm{CFU} / \mathrm{mL} V$. anguillarum & Haemocytes & Hsp40 & [75] \\
\hline $\begin{array}{l}\text { Asiatic hard clam } \\
\text { Meretrix meretrix }\end{array}$ & $\begin{array}{l}100 \mu \mathrm{l} / \mathrm{clam} \text { of } 5 \times 10^{6} \mathrm{cfu} / \mathrm{ml} \mathrm{V} \text {. parahaemolyticus } \\
\text { (MM21) }\end{array}$ & $\begin{array}{l}\text { Hepatopancreas } \\
\text { Gill }\end{array}$ & MmeHsc71 & {$[77]$} \\
\hline $\begin{array}{l}\text { Soft-shell clam } \\
\text { Mya arenaria }\end{array}$ & $\begin{array}{l}1 \times 10^{6} \text { cells/ml } \\
\text { V. splendidus (LGP32) }\end{array}$ & Haemocytes & $\begin{array}{l}\text { Hsp90 } \\
\text { Hsp83 }\end{array}$ & [76] \\
\hline $\begin{array}{l}\text { Chikong scallop } \\
\text { Chlamys farreri }\end{array}$ & $\begin{array}{l}50 \mu \mathrm{l} / \mathrm{scallop} V . \text { anguillarum, } \\
2.0 \times 10^{8} \text { cells } / \mathrm{ml}\end{array}$ & Haemocytes & Hsp22 & [74] \\
\hline $\begin{array}{l}\text { Bay scallop } \\
\text { Argopecten irradians }\end{array}$ & $\begin{array}{l}50 \mu \mathrm{l} / \mathrm{scallop} V . \text { anguillarum, } \\
2.0 \times 10^{8} \text { cells } / \mathrm{ml}\end{array}$ & Haemocytes & Hsp70 & [78] \\
\hline
\end{tabular}

Table 2: Induction of Hsp gene expression in aquatic organisms upon pathogen infection

Hsp70 production and shields gnotobiotic Artemia larvae against infection by $V$. campbellii and $V$. proteolyticus [16]. This resistance to bacteria may depend on the protection of proteins by Hsps in stressed cells and the greater tolerance to disease also implies a role for Hsps in shrimp immunity, perhaps through activation of TLRs. FcToll of the Chinese shrimp Fenneropenaeus chinensis predominantly expressed in the lymphoid organ, is a member of the insect-type Toll family [13]. FcToll increases following $V$. anguillarum contact and is reduced after white spot syndrome virus (WSSV) infection, suggesting involvement of the host innate immune defence system in protection against pathogenic Vibrios. Interaction between viruses and the TLRmediated NF- $\kappa B$ pathway has been revealed and, as for insects [80], a TLR/MyD88/Tube/Pelle/TRAF6/NF- $\kappa \mathrm{B}$ cascade may exist in the white shrimp for activation of immunity-related genes. Whatever the mechanism, these studies show that heat promotes Hsp70 expression and confers pathogen tolerance on Artemia larvae. Understanding the relationship between Hsps, the immune system and pathogen resistance is of importance in devising strategies to enhance disease tolerance in commercially exploited organisms.

Chemical inducers of Hsp synthesis: Several recently identified plant-based compounds shown to enhance Hsp synthesis in humans and animals have potential uses in aquaculture. TEX-OE ${ }^{\oplus}$, from the tropical cactus Opuntia ficus indica, is an effective non-stressful inducer of endogenous Hsps [9]. Application of Pro-Tex ${ }^{\circledR}$, the soluble variant of TEX-OE ${ }^{\oplus}$, either by immersion or as a feed additive accelerates fish and shellfish Hsp expression and boosts stress tolerance. For instance, immersion in Pro-Tex ${ }^{\oplus}$ protects fingerlings of the common carp Cyprinus carpio L. against acute ammonia stress with survival improving from 50 to $95 \%$ after incubation in $5.9 \mathrm{mg} / \mathrm{L} \mathrm{NH} 3$, the $1 \mathrm{~h}$ LC50 [80]. Remarkably, survival of carp exposed to Pro-Tex ${ }^{\circledR}$ increases by $20 \%$ over controls during lethal challenge with $14.2 \mathrm{mg} / \mathrm{L} \mathrm{NH}_{3}$. Amplification of Hsp70 in gills and muscle is evident, demonstrating that Pro-Tex ${ }^{\ominus}$ accelerates Hsp70 synthesis in carp in addition to preventing death. Immersion of the angel fish Pterophyllum scalare (Schultze) in TEX-OE ${ }^{\bullet}$ raises Hsp70 and Hsp90 synthesis in liver, muscle and gills, a change correlated with a two-fold improvement in protection against $1.1 \mathrm{mg} / \mathrm{L} \mathrm{NH}_{3}$, the $24 \mathrm{~h}$ LC50. Circulating Hsps are detected in TEX-OE ${ }^{\star}$ stimulated fish during $\mathrm{NH}_{3}$ stress at levels higher than those normally induced by heat [9]. Histological studies of gill tissue from moribund fish incubated with $\mathrm{NH}_{3}$ reveal lamellar oedema, necrosis of lamellar epithelial cells and clubbing of lamellar tips, whereas the gills in fish exposed to $\mathrm{TEX}-\mathrm{OE}^{\bullet}$ are structurally normal. These results suggest that Hsp accumulation afforded by TEX$\mathrm{OE}^{\circledR}$ safeguards against cell damage and/or promotes wound healing, conclusions similar to those for terrestrial animals $[9,82]$. 
The primary use of TEX-OE ${ }^{\oplus}$ in aquaculture is currently to reduce the effects of transport stress, particularly for salmon and sea bass [9]. However, TEX-OE ${ }^{\oplus}$ augments the disease tolerance of fish. As a case in point, Pro-Tex confers resistance against $V$. anguillarum infection of salmon and the gilthead sea bream Sparus aurata L [9], reducing mortality by half when compared to control fish. The mechanisms conferring tolerance to infection have yet to be determined but Hsps, as molecular chaperones, fold nascent and partially denatured proteins and they promote strong innate and adaptive immune responses. It is, therefore, of fundamental and applied significance to elucidate the immunoregulatory effects of bio-active compounds such as TEX-OE ${ }^{\oplus}$.

Paeoniflorin, from the herbal plant Paeonia lactiflora Pall, enhances Hsp70 expression in cultured mammalian cells and it is an alternative to TEX-OE ${ }^{\oplus}$. Paeoniflorin induces thermotolerance in HeLa cells, an effect intensified by heat shock at $42^{\circ} \mathrm{C}$ for $2 \mathrm{~h}$ [83]. The bioactive compound Celastrol, a quinone methide triterpene from the Chinese herbal medicine Celastraceace, increases the synthesis of Hsp70, Hsp40, and Hsp27 in HeLa cells. Celastrol activates HSF1 synergistically with stressors and confers protection against lethal heat shock at $42^{\circ} \mathrm{C}$ in HeLa cells and the neuroblastoma cell line SH-SY5Y [84]. Treatment with Schisandrin B (Sch B), the most active dibenzocyclooctadiene from the herb Schisandra chinensis, raises mouse hepatic Hsp70 in a dose-dependent manner and guards against hepatic cell apoptosis upon injection of D-galactosamine sensitized mice with TNF- $\alpha$ [85]. In a related study, Sch B provoked the synthesis of Hsp25 and Hsp70 in rat heart and shielded against ischemia reperfusion (I-R) injury. Hsp expression and protection against ischemia peak at 48 and $72 \mathrm{~h}$ postinjection, respectively [86]. Curcumin (diferuloylmethane), a major component of the turmeric plant Curcuma longa, induces Hsp70 expression in K562 cells. Hsp build-up, in addition to influencing antiinflammatory and anti-proliferative responses, is thought to be effective against chonic myelogenous leukemia [87]. Carvacrol, from the oil of Origanum species, brings about Hsp70 expression and promotes T cell recognition of endogenous $\mathrm{Hsp} 70$, as evidenced in vitro by the activation of an Hsp70-specific T cell hybridoma and in vivo by amplified $\mathrm{T}$ cell responses to this Hsp [88]. Carvacrol increases the number of spleen and joint $\mathrm{CD} 4+\mathrm{CD} 25+\mathrm{FoxP} 3+\mathrm{T}$ cells and suppresses experimental arthritis caused by proteoglycan. All of the compounds just described profoundly affect Hsp expression and/or disease tolerance in humans and other animals and it should be possible to exploit them in novel strategies to control disease of aquatic organisms. Such treatments, if successful, offer a decided advantage over many of the techniques presently used to curb disease in aquaculture.

Administration of exogenous Hsps: Feeding aquatic organisms with Hsp-enriched bacteria is a new approach to control disease in aquaculture. For example, supplying gnotobiotic larvae of Artemia with $E$. coli over-producing DnaK, the prokaryotic equivalent of Hsp70, enhances survival approximately two- to three-fold upon challenge with pathogenic $V$. campbellii [18]. Similar results were obtained when larvae were fed with heated bacterial strains LVS 2 (Bacillus sp), LVS 3 (Aeromonas hydrophila), LVS 8 (Vibrio sp), GR 8 (Cytophaga $s p$ ) and GR 10 (Roseobacter $s p$ ), all of which produce increased amounts of DnaK when compared to non-heated controls [19]. Immunoprobing of western blots and quantification by ELISA demonstrate that improvement in larval resistance to $V$. campbellii infection correlates with escalating amounts of DnaK, suggesting a protective role for this protein, either via chaperoning or by immune enhancement [19]. Support for an immunological effect is offered by the observation that feeding DnaK-enriched bacteria stimulates the prophenoloxidase (ProPO) cascade system of Artemia, a mechanism important for pathogen melanisation by the innate immune system [89]. Feeding Artemia with $\mathrm{mmn} 9$ yeast enriched in Hsp70 by heating, boosts Artemia tolerance against $V$. campbellii two-fold with effects apparent $36 \mathrm{~h}$ after challenge [15]. Heated gas1, a yeast strain with high chitin but low beta-glucan, contributes similar security against $V$. campbellii challenge. Taken together, these studies indicate that increases in disease tolerance occur in concert with the accretion of Hsps produced by either eukaryotic or prokaryotic cells and this may have practical applications in aquaculture.

Ingestion of E. coli over-producing Artemia Hsp70 shelters brine shrimp against $V$. campbellii, possibly by triggering the innate immune response to produce anti-inflammatory substances and suppress infection [14]. DnaK and Artemia Hsp70 exhibit 59.6\% similarity in the peptide-biding domain and the protective capacity of these proteins, termed the innate immunity-activation portion, may reside within this molecular domain, a conclusion similar to that made for Hsp70 from dendritic cells $[90,91]$.

Intracoelomic injection of the recombinant bacterial Hsps, DnaK and GroEL, the latter representing the prokaryotic equivalent of Hsp60, protects the platyfish Xiphophorus maculates against Yersinia ruckeri and the effect is amplified by non-lethal heat shock [20]. These data indicate a role for Hsps in increasing resistance against bacterial infections in fish, as seen for Artemia.

\section{Hsps and Immunity}

An intriguing observation indicating the influence of Hsps on fish and shellfish immunity is that the enhancement of Hsp70 synthesis in $P$. monodon by a short hyperthermic stress coincides with increased resistance against gill associated virus (GAV) [92]. GAV load is reduced for 21-days by heat shock but there is no response to osmotic and hypoxic stress, suggesting the lowered amount of virus is not attributable to holding animals under conditions preventing GAV replication, but from Hsp70 accumulation. A similar phenomenon occurs in Artemia where the build-up of Hsp70 in response to nonlethal heat shock protects against pathogenic $V$. campbellii and $V$. proteolyticus [16]. Likewise, a combined hypo- and hyper-thermic stress, followed by recovery at ambient temperature, brings about Hsp70 synthesis and shields Artemia larvae against V. campbellii [17]. The survival of Artemia larvae upon Vibrio challenge expands two-fold in each study and the rise in Hsp70 production coincides with increased resistance to bacteria, suggesting this and/or other Hsps protect larvae from infection. Hypothermic and osmotic stresses do not cause Hsp70 accumulation nor do they improve Artemia tolerance to Vibrios, indirectly implicating Hsp70 in resistance to pathogenic bacteria [93].

There are several mechanisms by which Hsps, and particularly Hsp70, guard against bacterial infection. Hsps may be required to stabilize cells against injury due to pathogen proliferation, for the proper folding of cell proteins synthesized in response to bacterial pathogens [94], for the storage and re-folding of partially denatured proteins and for stimulation of the innate immune response. As an example of immune stimulation, heat-induced sHsps and Hsp90 trigger nematode Caenorhabditis elegans immunity to pathogenic Pseudomonas aeruginosa by a process that engages HSF-1 and the DAF-2/DAF-16 pathway [95]. Increased Hsp70 reduces bacterial load in Artemia during challenge, an indication of immune system action [17]. Hsp70 is a ligand for Toll like receptors (TLRs) and shrimp may attenuate infection by way of these receptors [2]. Upon binding, Hsps activate TLRs, transferring inflammatory signals to cells of the innate immune system and promoting resistance against disease [96-98]. TLRs 
have yet to be characterized in Artemia but in another crustacean, the white shrimp, they contain an extracellular domain with 16 leucinerich repeats (LRRs) flanked by cysteine-rich motifs and a cytoplasmic Toll/interleukin-1 receptor (TIR) domain, the latter with $59.9 \%$ and $54.3 \%$ identity, respectively, to corresponding proteins in the Western honey bee Apis mellifera and fruit fly Drosophila melanogaster [99]. Characterization of a novel cDNA from the gills of $P$. monodon yielded a protein with a deduced amino acid sequence $59 \%$ similar to an $A$. mellifera Toll-related protein [100]. Collectively, these findings suggest that Hsps stimulate the immune system in Artemia and other shrimp, thereby promoting pathogen recognition and destruction.

Like other invertebrates, shrimp and bivalves lack the adaptive immune system and their ability to eliminate pathogens depends on the cooperation of innate cellular and humoral mechanisms. The haemocytes of shellfish play a key role in phagocytosis, the major cellular immune response against pathogens [101-103]. Phagocytosis functions with other components of the immune system such as prophenoloxidase (ProPO) [14] and antimicrobial peptides [104]. Large amounts of Hsp70 are released from the haemocytes of $L$. vannamei following infection by $V$. alginolyticus [71], results similar to those for the Pearl Oyster Pinctada fucata, a marine bivalve [105]. The up-regulation of Hsps in haemocytes upon bacterial and viral exposure links Hsps with the immune system but it is unclear if Hsp70 from shrimp and bivalve haemocytes stimulates immunity. However, Hsps are thought to maintain phagocytic cells [106] either by repairing damage or safeguarding against autolysis and apoptosis due to autooxidation brought about by internal defence systems [8]. Preserving haemocytes is of primary importance to ensure the degradation of infectious pathogens $[101,102]$.

As for invertebrates, the role of Hsps in the fish immune system is poorly defined although several studies are available on Hsp gene expression following bacterial and viral contact. Use of the peripheral blood lymphocyte (PBL)/lipopolysaccharide (LPS) model from the grass carp Ctenopharyngodon idella has aided research on fish immunity and shed light on Hsp70 function [107]. In reaction to LPS, an endotoxin of the outer membrane of Gram-negative bacteria, the expression of grass carp genes encoding $\mathrm{Hsp} 70 / \mathrm{Hsc70}$ is enhanced in twelve immune-related tissues including PBLs, head kidney, kidney, spleen, intestines, gill and thymus. The abundance of Hsp70/ Hsc70 in PBLs indicates selective modulation of gene expression and the detection of extracellular Hsp70 implies that release of this Hsp contributes to immunity. Extracellular Hsps are postulated to mediate production of cell surface peptides, thus helping the immune

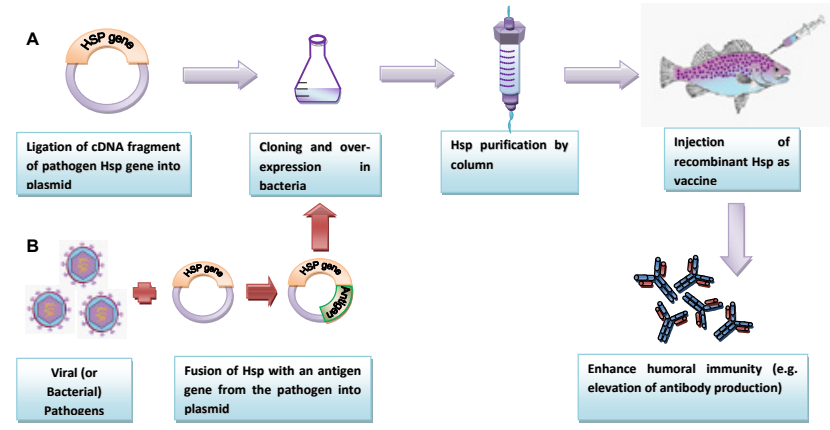

Figure 1: Immunization of fish with Hsp-based vaccines. (A) cDNA encoding a pathogen $\mathrm{Hsp}$ and $(\mathrm{B}) \mathrm{cDNA}$ encoding a $\mathrm{Hsp}$ fused with a pathogen antigen are cloned and over-expressed in bacteria. The expressed protein is purified and injected into host organisms to enhance immunity. system recognize distressed cells $[65,108,109]$. Hsp70 communicates inflammatory "danger signals" to immune cells such as monocytes, dendrites, neutrophils and macrophages $[108,110,111]$ via stimulation of TLR2 and TLR4 $[96,112,113]$. The secretion of inflammatory cytokines, nitric oxide (NO) synthase, NO, tumor necrosis factor-alpha (TNF- $\alpha$, Interleukin1-beta (IL-1 $\beta$ and IL-6 from macrophages and neutrophils is intensified by Hsps [114]. During adaptive immunity Hsps may play an integral part in antigen presentation via assembly of major histocompatibility complex (MHC) - peptide complexes, activating $\mathrm{T}$ cells to destroy or co-ordinate the killing of pathogens and infected, malfunctioning cells $[11,98]$. Class I and class II MHC are membrane-bound glycoproteins responsible for presenting processed antigens to $\mathrm{CD}^{+}$and $\mathrm{CD}^{+}{ }^{+} \mathrm{T}$ lymphocytes. Teleost fish MHCs are equivalent to their mammalian counterparts in exon-intron organization and polymorphism of their genes and in protein structure [115]. Understanding the role of extracellular Hsp70 released from fish lymphocytes and the functions of other Hsps in immune regulation is likely to reveal strategies for the protection of fish and shellfish, this of particular use in aquaculture where infection and disease are major obstacles to increasing productivity.

\section{Hsp-Based Vaccines Restrict Infection by Pathogens}

Vaccines raised against bacteria and viruses for delivery by immersion, injection and orally, prevent fish disease and they offer important alternatives to antibiotic use by providing long-lasting protection with little or no adverse environmental effect [116]. Attenuated pathogens are commonly used in vaccine production for immunization of fish [117], but interest has grown in the use of Hsps for this purpose. Pathogen derived Hsps are dominant antigens in many microbial infections and they have been used successfully to generate vaccines against bacterial fish pathogens [2,117]. To obtain Hsps for immunization, cDNAs encoding pathogen Hsps are cloned, over-expressed in bacteria and purified after which they are introduced into host organisms (Figure 1).

Injection with Hsp60 and Hsp70 from Piscirickettsia salmonis protects Atlantic salmon Salmo salar against P. salmonis infection, boosting survival by $89.6 \%$ at 50 days post-challenge when compared to non-immunized controls [118]. Characterization of a novel immunogenic agent termed ChaPs synthesized by $P$. salmonis obtained from infected salmonid fish, reveals a prokaryotic Hsp, supporting the idea that bacterial Hsps are suitable for development of vaccines against salmonid rickettsial septicemia (SRS) [21], a disease responsible for massive mortalities of salmon worldwide. Moreover, vaccination with purified DnaJ, the prokaryotic homologue of Hsp40, from Edwardsiella tarda shields the Japanese flounder Paralichthys olivaceus against this Gram negative pathogen, increasing survival by $62 \%$ over non-immunized controls [22].

Flavobacterium psychrophilum $\mathrm{Hsp} 60$ and Hsp70 are highly immunogenic [119], but vaccination with these proteins alone, or in combination, does not safeguard the rainbow trout Oncorhynchus mykiss against infection. Antibody titres to Hsps remain low even 4 weeks post-immunization $[117,120]$. However, a fusion protein composed of Hsp70 and a protein or peptide from a pathogen is highly immunogenic, apparently because the Hsp70 functions as an adjuvant. As one example, fusing Mycobacterium Hsp70 with p24, an HIV protein, induces higher production of antibodies to p24 and more interferon than does Hsp70 or p24 when acting alone [117,121]. A novel vaccine raised against a fusion protein composed of Infectious Salmon Anemia Virus (ISAV) protein subunits and fish Hsps is being tested for use in aquaculture [122]. Employing Hsps for immunization 
Citation: Sung YY, MacRae TH (2011) Heat Shock Proteins and Disease Control in Aquatic Organisms. J Aquac Res Development S2:006. doi:10.4172/2155-9546.S2-006

offers a seemingly effective approach for disease control with potential applications in many different commercially important aquatic organisms while reducing the environmental impact of aquaculture operations.

\section{Conclusions}

Aquatic organisms respond to pathogen infection by the production of sHsps, Hsp70, Hsp90 and Hsp60, all of which function as molecular chaperones and protect cells during stress. That is, Hsps modulate the folding of nascent proteins, prevent irreversible protein denaturation and either refold or assist in the elimination of damaged proteins. Finfish, shellfish and bivalves synthesize Hsps in response to bacterial and viral infections indicating a role for these proteins in disease resistance. Increasing Hsps in aquatic organisms by heat shock, chemical application and feeding exogenous Hsps also enhances resistance to infection. The level of tolerance correlates with the amount of accumulated Hsp. In addition to protecting proteins Hsps are thought to improve resistance to pathogens by stimulating humoral and cellular aspects of host innate immunity, perhaps best explaining how the feeding of exogenous Hsps contributes to disease tolerance. Further studies with Artemia are of particular interest in the context of feeding Hsps to host animals as a protective strategy. Hsps, either in isolation from other proteins or fused to pathogen-derived antigens are effective vaccines for the prevention of disease in aquatic organisms. Vaccine targets include Hsps from pathogens which are produced in abundance upon infection and pathogen protein/peptides fused to Hsps. Clearly, there is a strong case for exploring Hsps as agents of disease resistance and an excellent possibility that their application will present a significant advance in preventing diseases of aquatic organisms used for aquaculture.

\section{Acknowledgements}

This work was supported by the E-Science Fund Project No. 05-01-12-SF1006 and 05-01-12-SF1020 from the Ministry of Agriculture (MOA), Malaysia to YYS, and by a Discovery Grant from the Natural Sciences and Engineering Research Council of Canada to THM.

\section{References}

1. Pockley AG, Muthana M, Calderwood SK (2008) The dual immunoregulatory roles of stress proteins. Trends Biochem Sci 33: 71-79.

2. Sung $Y Y$, MacRae TH, Sorgeloos $P$, Bossier $P$ (2011) Stress Response for Disease Control in Aquaculture. Rev Aquacult 3: 120-137.

3. Pockley AG (2003) Heat shock proteins as regulators of the immune response. Lancet 362: 469-476.

4. Sun Y, MacRae TH (2005) Small heat shock proteins: molecular structure and chaperone function. Cell Mol Life Sci 62: 2460-2476.

5. Clegg JS, Jackson SA, Hoa NV, Sorgeloos P (2000) Thermal resistance, developmental rate and heat shock proteins in Artemia franciscana, from San Francisco Bay and Southern Vietnam. J Exp Mar Biol Ecol 252: 85-96.

6. Brown HM, Briden A, Stokell T, Griffin FJ, Cherr GN (2004) Thermotolerance and Hsp70 profiles in adult and embryonic California native oysters, Ostreola conchaphila (Carpenter, 1857). J Shellfish Res 23: 135-141.

7. Brun NT, Bricelj VN, MacRae TH, Ross NW (2009)Acquisition of thermotolerance in bay scallops, Argopecten irradians irradians, via differential induction of heat shock proteins. J Exp Mar Biol Ecol 371: 77-83.

8. Basu N, Todgham AEP, Ackerman A, Bibeau MR, Nakano K, et al. (2002) Heat shock protein genes and their functional significance in fish. Gene 295: 173183

9. Roberts RJ, Agius C, Saliba C, Bossier P, Sung YY (2010) Heat Shock Proteins (Chaperones) in Fishes and Shellfishes and their Potential Role in Health and Welfare: A Review. J Fish Dis 33: 789-801.
10. Iwama GK, Afonso LOB, Todgham A, Ackerman P, Nakano K (2004) Are hsps suitable for indicating stressed states in fish. J Exp Biol 207: 15-19.

11. Srivastava $P(2002)$ Interaction of heat shock proteins with peptides and antigen presenting cells: chaperoning of the innate and adaptive immune responses. Annu Rev Immunol 20: 395-425.

12. Wieten L, van der Zee R, Spiering R, Wagenaar-Hilbers J, van Kooten P, et al (2010) A Novel Heat-Shock Protein Coinducer Boosts Stress Protein Hsp70 to Activate T Cell Regulation of Inflammation in Autoimmune Arthritis. Arthritis Rheum 62: 1026-1035.

13. Yang C, Zhang J, Li F, Ma H, Zhang Q, et al. (2008) A Toll receptor from Chinese shrimp Fenneropenaeus chinensis is responsive to Vibrio anguillarum infection. Fish Shellfish Immunol 24: 564-574.

14. Baruah K, Ranjan J, Sorgeloos P, Bossier P (2010) Efficacy of heterologous and homologous heat shock protein $70 \mathrm{~s}$ as protective agents to Artemia franciscana challenged with Vibrio campbellii. Fish Shellfish Immunol 29: 733739.

15. Wang L, Baruah K, Fan T, Yu M, Bossier P (2010) Influence of heat shock proteins induction in different yeast cell wall mutants on the protection against Vibrio campbellii infection in gnotobiotically grown Artemia franciscana (Kellogg). J Fish Dis 33: 919-923.

16. Sung YY, Van Damme EJM, Sorgeloos $P$, Bossier $P$ (2007) Non-lethal heat shock protects gnotobiotic Artemia franciscana larvae against virulent Vibrios. Fish Shellfish Immunol 22: 318-326.

17. Sung YY, Pineda C, MacRae TH, Sorgeloos P, Bossier P (2008) Exposure of gnotobiotic Artemia franciscana larvae to abiotic stress promotes heat shock protein 70 synthesis and enhances resistance to pathogenic Vibrio campbellii. Cell Stress Chaperones 13: 59-66.

18. Sung YY, Ashame MF, Chen SJ, MacRae TH, Sorgeloos P, et al. (2009a) Feeding Artemia franciscana (Kellogg) larvae with bacterial heat shock protein protects from Vibrio campbellii (Baumann) infection. J Fish Dis 32: 675-685.

19. Sung YY, Dhaene T, Defoirdt T, Boon N, MacRae TH, et al. (2009b) Ingestion of bacteria over-producing DnaK attenuates Vibrio infection of gnotobiotic Artemia franciscana larvae. Cell Stress Chaperones 14: 603-609.

20. Ryckaert J, Pasmans F, Tobback E, Duchateau L, Decostere A, et al. (2010) Heat shock proteins protect platyfish (Xiphophorus maculatus) from Yersinia ruckeri induced mortality. Fish Shellfish Immunol 28: 228-231.

21. Marshall SH, Conejeros P, Zahr M, Olivares J, Gómez F, et al. (2007) Immunological characterization of a bacterial protein isolated from salmonid fish naturally infected with Piscirickettsia salmonis. Vaccine 25: 2095-2102.

22. Dang W, Zhang M, Sun L (2011) Edwardsiella tarda DnaJ is a virulenceassociated molecular chaperones with immunoprotective potential. Fish Shellfish Immunol 31: 182-188.

23. Mchaourab HS, Godar JA, Stewart PL (2009) Structure and mechanism of protein stability sensors: chaperone activity of small heat shock proteins. Biochem 48: 3828-3837.

24. Hilario E, Martin FJM, Bertolini MC, Fan L (2011) Crystal structures of Xanthomonas small heat shock protein provide a structural basis for an active molecular chaperone oligomer. J Mol Biol 408: 74-86.

25. Kennaway CK, Benesch JL, Gohlke U, Wang L, Robinson CV, et al. (2005) Dodecemeric structure of the small heat shock protein Acr1 from Mycobacterium tuberculosis. J Biol Chem 280: 33419-33425.

26. Laganowsky A, Benesch JLP, Landau M, Ding L, Sawaya MR, et al. (2010) Crystal structures of truncated alphaA and alphaB crystallins reveal structural mechanisms of polydispersity important for eye lens function. Protein Sci 19: 1031-1043.

27. Jehle S, Vollmar BS, Bardiaux B, Dove KK, Rajagopal P, et al. (2011) N-termina domain of aB-crystallin provides a conformational switch for multimerization and structural heterogeneity. Proc Natl Acad Sci USA 108: 6409-6414.

28. Wu Y, MacRae TH (2010) Truncation attenuates molecular chaperoning and apoptosis inhibition by p26, a small heat shock protein from Artemia franciscana. Biochem Cell Biol 88: 937-946.

29. Chen J, Feige MJ, Franzmann TM, Bepperling A, Buchner J (2010) Regions outside the $\alpha$-crystallin domain of the small heat shock protein Hsp26 are required for its dimerization. $\mathrm{J} \mathrm{Mol} \mathrm{Biol} \mathrm{398:} \mathrm{122-131.}$ 
Citation: Sung YY, MacRae TH (2011) Heat Shock Proteins and Disease Control in Aquatic Organisms. J Aquac Res Development S2:006. doi:10.4172/2155-9546.S2-006

Page 8 of 10

30. Franzmann TM, Wühr M, Richter K, Walter S, Buchner J (2005) The activation mechanism of Hsp26 does not require dissociation of the oligomer. J Mol Biol 350: 1083-1093

31. Benesch JLP, Ayoub M, Robinson CV, Aquilina JA (2008) Small heat shock protein activity is regulated by variable oligomeric substructure. $\mathrm{J}$ Biol Chem 283: 28513-28517.

32. Takeda K, Hayashi T, Abe T, Hirano Y, Hanazono Y, et al. (2011) Dimer structure and conformational variability in the $\mathrm{N}$-terminal region of an archaeal small heat shock protein, StHsp14.0. J Struct Biol 174: 92-99.

33. Ehrnsperger M, Gräber S, Gaestel M, Buchner J (1997) Binding of non-native protein to Hsp25 during heat shock creates a reservoir of folding intermediates for reactivation. EMBO J 16: 221-229.

34. Lee GJ, Vierling E (2000) A small heat shock protein cooperates with heat shock protein 70 systems to reactivate a heat-denatured protein. Plant Physiol 122: 189-198.

35. Schlecht R, Erbse AH, Bukau B, Mayer MP (2011) Mechanics of Hsp70 chaperones enables differential interaction with client proteins. Nat Struct Mol Biol 18: 345-351.

36. Marcinowski M, Höller M, Feige MJ, Baerend D, Lamb DC, et al. (2011) Substrate discrimination of the chaperone BiP by autonomous and cochaperoneregulated conformational transitions. Nat Struct Mol Biol 18: 150-158.

37. Bertelsen EB, Chang L, Gestwicki JE, Zuidweg ER (2009) Solution conformation of wild type E. coli Hsp70 (DnaK) chaperone complexed with ADP and substrate. Proc Natl Acad Sci USA 106: 8471-8476.

38. Hartl FU, Hayer-Hartl K (2009) Converging concepts of proteins folding in vitro and in vivo. Nat Struct Mol Biol 16: 574-581.

39. Kabbage M, Dickman MB (2008) The BAG proteins: a ubiquitous family of chaperone regulators. Cell Mol Life Sci 65: 1390-1402.

40. Kampinga HH, Craig EA (2010) The HSP70 chaperone machinery: J proteins as drivers of functional specificity. Nat Rev Mol Cell Biol 11: 579-592.

41. Young JC (2010) Mechanisms of the Hsp70 chaperone system. Biochem Cel Biol 88: 291-300

42. Böcking T, Aguet F, Harrison SC, Kirchhausen T (2011) Single-molecule analysis of a molecular disassemblase reveals the mechanism of Hsc70-driven clathrin uncoating. Nat Struct Mol Biol 18: 295-301.

43. Hagn F, Lagleder S, Retzlaff M, Rohrberg J, Demmer O, et al. (2011) Structural analysis of the interaction between Hsp90 and the tumor suppressor protein p53. Nat Struct Mol Biol 18: 1086-1093.

44. Street TO, Lavery LA, Agard DA (2011) Substrate binding drives large-scale conformation changes in the Hsp90 molecular chaperones. Mol Cell 42: 96105

45. Park SJ, Borin BN, Martinez-Yamout MA, Dyson HJ (2011) The client protein p53 adopts a molten globule-like state in the presence of Hsp90. Nat Struct Mol Biol 18: 537-541

46. Pratt WB, Morishima Y, Osawa Y (2008) The Hsp90 chaperone machinery regulates signaling by modulating ligand binding clefts. J Biol Chem 283: 22885-22889.

47. Theodoraki MA, Caplan AJ (2011) Quality control and fate determination of Hsp90 client proteins. Biochim Biophys Acta (in press).

48. Taipale M, Jarosz DF, Lindquist S (2010) Hsp90 at the hub of protein homeostasis: emerging mechanistic insights. Nat Rev Mol Cell Biol 11: 515528

49. Krukenberg KA, Street TO, Lavery LA, Agard DA (2011) Conformational dynamics of the molecular chaperone Hsp90. Q Rev Biophys 44: 229-255.

50. Onuoha SC, Coulstock ET, Grossman JG, Jackson SE (2008) Structural studies on the co-chaperones Hop and its complexes with Hsp90. J Mol Biol 379: $732-744$.

51. Cong Y, Baker ML, Jakana J, Woolford D, Miller EJ, et al. (2010) 4.0Å resolution cryo-EM structure of the mammalian chaperonin TriC/CCT reveals its unique subunit arrangement. Proc Natl Acad Sci USA 107: 4967-4972.

52. Yébenes H, Mesa P, Muňoz IG, Montoya G, Valpuesta JM (2011) Chaperonins: two rings for folding. Trends Biochem Sci 38: 424-432.

53. Speiss C, Miller EJ, McClellan, Frydman J (2006) Indentification of the TriC/
CCT substrate binding site uncovers the function of subunit diversity in eukaryotic chaperonins. Mol Cell 24: 25-37.

54. Reissmann S, Parnot C, Booth CR, Chiu W, Frydman J (2007) Essentia function of the built-in lid in the allosteric regulation of eukaryotic and archaea chaperonins. Nat Struct Mol Biol 14: 432-440.

55. Pereira JH, Ralston CY, Douglas NR, Meyer D, Knee KM, et al. (2010) Crysta structures of a group II chaperonin reveal the open and closed states associated with the protein folding cycle. J Biol Chem 285: 27958-27966.

56. Douglas N, Reissmann S, Zhang J, Chen B, Jakana J, et al. (2011) Dual action of ATP hydrolysis couples lid closure to substrate release into the group I chaperonin chamber. Cell 144: 240-252.

57. Yam AY, Xia Y, Lin HJ, Burlingame A, Gerstein M, et al. (2008) Defining the TRiC/CCT interactome links chaperonin function to stabilization of newly made proteins with complex topologies. Nat Struct Mol Biol 15: 1255-1262.

58. Brackley KI, Grantham J (2009) Activities of the chaperonin containing TCP1 (CCT): implications for cell cycle progression and cytoskeletal organisation. Cell Stress Chaperones 14: 23-31.

59. Lee JY, Cho WJ, Do JW. Kim HJ, Park JW, et al. (1996) Monoclonal antibodies raised against infectious haematopoietic necrosis virus (IHNV) G protein and a cellular 90kDa protein neutralize IHNV infection in vitro. J Gen Virol 77: 17311737

60. Deane EE, Woo NYS (2011) Advances and perspectives on the regulation and expression of piscine heat shock proteins. Rev Fish Biol Fisher 21: 153-185.

61. Chen YM, Kuo CE, Wang TY, Shie PS, Wang WC, et al. (2010) Cloning of an orange-spotted grouper Epinephelus coioides heat shock protein $90 \mathrm{AB}$ (HSP90AB) and characterization of its expression in response to nodavirus. Fish Shellfish Immunol 28: 895-904.

62. Dong CW, Zhang YB, Zhang QY, Gui JF (2006) Differential expression of three Paralichthys olivaceus Hsp40 genes in responses to virus infection and heat shock. Fish Shellfish Immunol 21: 146-158.

63. Forsyth RB, Candido PM, Babich SL, Iwama GK (1997) Stress protein expression in coho salmon with Bacterial Kidney Disease. J Aquat Anim Health 9: $18-25$.

64. Ackerman A, Iwama GK (2001) Physiological and cellular response of juvenile rainbow trout to vibriosis. J Aquat Anim Health 13: 173-180.

65. Deane EE, Li J, Woo NYS (2004) Modulated heat shock protein expression during pathogenic Vibrio alginolyticus stress of sea bream. Dis Aquat Org 62 205-215.

66. Wang B, Li F, Dong B, Zhang X, Zhang C, et al. (2006) Discovery of the Genes in Response to White Spot Syndrome Virus (WSSV) Infection in Fenneropenaeus chinensis through cDNA Microarray. Mar Biotechnol 8: 491-500.

67. Liu W, Qian D, Yan X (2011) Proteomic analysis of differentially expressed proteins in hemolymph of Scylla serrata response to white spot syndrome virus infection. Aquaculture 314: 53-57.

68. Cui Z, Liu Y, Luan W, Li Q, Wu D, et al. (2010) Molecular cloning and characterization of a heat shock protein 70 gene in swimming crab (Portunus trituberculatus). Fish Shellfish Immunol 28: 56-64.

69. Rungrassamee W, Leelatanawit $R$, Jiravanichpaisal $P$, Klinbunga $S$ Karoonuthaisiri N (2010) Expression and distribution of three heat shock protein genes under heat shock stress and under exposure to Vibrio harveyi in Penaeus monodon. Dev Comp Immunol 34: 1082-1089.

70. Somboonwiwat K, Chaikeeratisak V, Wang HC, Lo CF, Tassanakajon A (2010) Proteomic analysis of differentially expressed proteins in Penaeus monodon hemocytes after Vibrio harveyi infection. Proteome Sci 8: 39.

71. Zhou J, Wang L, Xin Y, Wang WN, He WY, et al. (2010) Effect of temperature on antioxidant enzyme gene expression and stress protein response in white shrimp, Litopenaeus vannamei. J Thermal Biol 35: 284-289.

72. Li C, Wang L, Ning X, Chen A, Zhang L, et al. (2010) Identification of two small heat shock proteins with different response profile to cadmium and pathogen stresses in Venerupis philippinarum. Cell Stress Chaperones 15: 897-904

73. Bao Y, Wang Q, Liu H, Lin Z (2011)A small HSP gene of bloody clam (Tegillarca granosa) involved in the immune response against Vibrio parahaemolyticus and lipopolysaccharide. Fish Shellfish Immunol 30: 729-733.

74. Zhang L, Wang L, Zhao J, Qiu L, Song L et al. (2009) The responsive expression 
Citation: Sung YY, MacRae TH (2011) Heat Shock Proteins and Disease Control in Aquatic Organisms. J Aquac Res Development S2:006. doi:10.4172/2155-9546.S2-006

Page 9 of 10

of heat shock protein 22 gene in zhikong scallop Chlamys farreri against a bacterial challenge. J Aquacult Res 41: 257-266.

75. Li C, Li L, Liu F, Ning X, Chen A, et al. (2011) Alternation of Venerupis philippinarum Hsp40 gene expression in response to pathogen challenge and heavy metal exposure. Fish Shellfish Immunol 30: 447-450.

76. Araya MT, Markham F, Mateo DR, McKenna P, Johnson GR, et al. (2010) Identification and expression of immune-related genes in hemocytes of softshell clams, Mya arenaria, challenged with Vibrio splendidus. Fish \& Shellfish Immunology 29: 557-564.

77. Yue X, Liu B, Sun L, Tang B (2011) Cloning and characterization of a hsp70 gene from Asiatic hard clam Meretrix meretrix which is involved in the immune response against bacterial infection. Fish Shellfish Immunol 30: 791-799.

78. Song L, Wu L, Ni D, Chang Y, Xu W, et al. (2006) The cDNA cloning and mRNA expression of heat shock protein 70 gene in the haemocytes of bay scallop (Argopecten irradians, Lamarck 1819) responding to bacteria challenge and naphthalin stress. Fish Shellfish Immunol 21: 335-345.

79. Puerto M, Campos A, Prieto A, Cameán A, de Almeida AM, et al. (2011) Differential protein expression in two bivalve species; Mytilus galloprovincialis and Corbicula fluminea; exposed to Cylindrospermopsis raciborskii cells. Aquat Toxicol 101: 109-116.

80. Wang PH, Gu ZH, Wan DH, Zhang MY, Weng SP, et al. (2011) The Shrimp NF-kB Pathway Is Activated by White Spot Syndrome Virus (WSSV) 449 to Facilitate the Expression of WSSV069 (ie1), WSSV303 and WSSV371. PLoS ONE 6: e24773.

81. Sung YY, Roberts RJ, Bossier P (2011) Enhancement of Hsp70 synthesis protects common carp Cyprinus carpio L. against lethal ammonia toxicity. J Fish Dis (In press).

82. Sandilands J, Drynan KD, Roberts RJ (2010) Preliminary studies on the enhancement of storage time of chilled milt of Atlantic salmon, Salmo salar $\mathrm{L}$., using an extender containing the TEX-OE heat shock-stimulating factor. Aquaculture Res 41: 568-571.

83. Yan D, Saito K, Ohmi Y, Fujie N, Ohtsuka K (2004) Paeoniflorin, a novel heat shock protein-inducing compound. Cell Stress Chaperones 9: 378-389.

84. Westerheide SD, Bosman JD, Mbadugha BNA, Kawahara TLA, Matsumoto G, et al. (2004) Celastrols as Inducers of the Heat Shock Response and Cytoprotection. J Biol Chem 279: 56053-56060.

85. Ip SP, Che CT, Kong YC, Ko KM (2001) Effects of Schisandrin B pretreatment on tumor necrosis factor-a induced apoptosis and Hsp70 expression in mouse liver. Cell Stress Chaperones 6: 44-48.

86. Chiu PY, Ko KM (2004) Schisandrin B protects myocardial ischemia-reperfusion injury partly by inducing $\mathrm{Hsp} 25$ and Hsp70 expression in rats. Mol Cell Biochem 266: 139-144.

87. Teiten MH, Eifes S, Reuter S, Duvoix A, Dicato M, et al. (2009) Gene Expression Profiling Related to Anti-inflammatory Properties of Curcumin in K562 Leukemia Cells. Ann NY Acad Sci 1171: 391-398.

88. Wieten L, Broere F, van der Zee R, Koerkamp EK, Wagenaar J, et al. (2007) Cell stress induced HSP are targets of regulatory T cells: A role for HSP inducing compounds as anti-inflammatory immuno-modulators? FEBS Lett 581: $3716-3722$

89. Baruah K, Ranjan J, Sorgeloos P, MacRae TH, Bossier P (2011) Priming the prophenoloxidase system of Artemia franciscana by heat shock proteins protects against Vibrio campbellii challenge. Fish Shellfish Immunol 31: 134141

90. MacAry PA, Javid B, Floto RA, Smith KGC, Oehlmann KGC, et al. (2004) HSP70 peptide binding mutants separate antigen delivery from dendritic cell stimulation. Immunity 20: 95-106.

91. Wang Y, Whittall T, McGowan E, Younson J, Kelly C, et al. (2005) Identification of stimulating and inhibitory epitopes within the heat shock protein 70 molecule that modulate cytokine production and maturation of dendritic cells. J Immunol 174: $3306-3316$.

92. de la Vega E, Hall MR, Degnan BM, Wilson KJ (2006) Short-term hyperthermic treatment of Penaeus monodon increases expression of heat shock protein 70 (HSP70) and reduces replication of gill associated virus (GAV). Aquaculture 253: 82-90.

93. Sung YY (2008) Protection of Artemia from vibriosis by heat shock and heat shock proteins. PhD thesis, Ghent University, Belgium. ISBN number: 978-905989-224-8.

94. Singh V, Aballay A (2006) Heat-shock and gene activation of HSF-1 enhance immunity to bacteria. Cell cycle 5: 2443-2446.

95. Singh V, Aballay A (2006) Heat-shock transcription factor (HSF)-1 pathway required for Caenorhabditis elegans immunity. Proc Natl Acad Sci USA 103: 13092-13097.

96. Vabulas RM, Ahmad-Nejad P, Ghose S, Kirschning CJ, Issels RD, et al. (2002) HSP70 as endogenous stimulus of the Toll/interleukin-1 receptor signal pathway. J Biol Chem 277: 15107-15112.

97. Gobert V, Gottar M, Matskevich AA, Rutschmann S, Royet J, et al. (2003) Dual activation of the Drosophila toll pathway by two pattern recognition receptors. Science 302: 2126-2130.

98. Kulkarni R, Behboudi S, Sharif S (2011) Insights into the role of Toll-like receptors in modulation of T cell responses. Cell Tissue Res 343: 141-152.

99. Yang LS, Yin ZX, Liao JX, Huang XD, Guo CJ, et al. (2007) A Toll receptor in shrimp. Mol Immunol 44: 1999-2008.

100. Arts JAJ, Cornelissen FHJ, Cijsouw T, Hermsen T, Savelkoul HFJ, et al. (2007) Molecular cloning and expression of a Toll-receptor in the giant tiger shrimp, Penaeus monodon. Fish Shellfish Immunol 23: 504-513.

101. Cheng TC (1981) Bivalves. In: N. A. Ratcliffe and A. F. Rowley, Editors, Invertebrate Blood Cells. Academic Press. London. 233-299.

102. Feng SY (1988) Cellular defense mechanisms of oysters and mussels. Am Fish Soc Special Publication 18: 153-168.

103. Fabbri E, Valbonesi P, Franzellitti S (2008) Hsp expression in bivalves. Inv Surv J 5: 135-161.

104. Cellura C, Toubiana M, Parrinello N, Roch P (2007) Specific expression of antimicrobial peptide and HSP70 genes in response to heat-shock and several bacterial challenges in mussels. Fish Shellfish Immunol 22: 340-350.

105. Wang Z, Wu Z, Jian J, Lu Y (2009) Cloning and expression of heat shock protein 70 gene in the haemocytes of pearl oyster (Pinctada fucata, Gould 1850) responding to bacterial challenge. Fish Shellfish Immunol 26: 639-645.

106. Polla BS, Stubbe H, Kantengwa S, Maridonneau-Parini I, Jacquier-Sarlin MR (1995) Differential induction of stress proteins and functional effects of heat shock in human phagocytes. Inflammation 19: 368-378.

107. Zhang A, Zhou X, Wang X, Zhou H (2011) Characterization of two hea shock proteins (Hsp70/Hsc70) from grass carp (Ctenopharyngodon idella): Evidence for their differential gene expression, protein synthesis and secretion in LPS-challenged peripheral blood lymphocytes. Comp Biochem Physiol Part B 159: 109-114.

108. Moseley $P$ (2000) Stress proteins and the immune response. Int Immunopharmacol 48: 299-302.

109. Henderson B, Calderwood SK, Coates ARM, Cohen I, van Eden W, et al. (2010) Caught with their PAMPs down? The extracellular signaling actions of molecular chaperones are not due to microbial contaminants. Cell Stress Chaperones 15: 123-141.

110. Breloer M, Dorner B, More SH, Roderian T, Fleischer B, et al. (2001) Heat shock proteins as "danger signals": eukaryotic Hsp60 enhances and accelerates antigen-specific IFN-y production in T cells. Eur J Immunol 31: 2051-2059.

111. Fleshner M, Johnson JD (2005) Exogenous extra-cellular heat shock protein 72: releasing signal(s) and functions. Int J Hyperthermia 21: 457-471.

112. Asea A, Rehli M, Kabingu E, Boch JA, Bare O, et al. (2002) Novel signal transduction pathway utilized by extracellular HSP70: role of Toll-like receptor (TLR) 2 and TLR4. J Biol Chem 277: 15028-15034.

113. Cuellar A, Santander SP, Thomas MDC, Guzman F, Gomez A, et al. (2008) Monocyte-derived dendritic cells from chagasic patients vs healthy donors secrete differential level of IL-10 and IL-12 when stimulated with a protein fragment of Trypanosoma cruzi heat-shock protein 70. Immunol Cell Biol 86 255-260.

114. Johnson JD, Fleshner M (2006) Releasing signals, secretory pathways, and immune function of endogenous extracellular heat shock protein 72 . J Leukoc Biol 79: 425-434. 
Citation: Sung YY, MacRae TH (2011) Heat Shock Proteins and Disease Control in Aquatic Organisms. J Aquac Res Development S2:006. doi:10.4172/2155-9546.S2-006

115. Cuesta A, Esteban MA, Meseguer J (2006) Cloning, distribution and up-regulation of the teleost fish MHC class II alpha suggests a role for granulocytes as antigen-presenting cells. Mol Immunol 43: 1275-1285.

116. Grisez L, Tan Z (2005) Vaccine development for Asian aquaculture. In P. Walker, R. Lester and M.G. Bondad-Reantaso (eds). Diseases in Asian Aquaculture V, pp. 483-494. Fish Health Section, Asian Fisheries Society, Manila.

117. Plant KP, LaPatra SE, Cain KD (2009) Vaccination of rainbow trout, Oncorhynchus mykiss (Walbaum), with recombinant and DNA vaccines produced to Flavobacterium psychrophilum heat shock proteins 60 and 70 . J Fish Dis 32: 521-534.

118. Wilhelm V, Soza C, Martínez R, Rosemblatt M, Burzio LO, et al. (2005) Production and immune response of recombinant $\mathrm{Hsp} 60$ and Hsp70 from the salmon pathogen Piscirickettsia salmonis. Biol Res 38: 69-82.
119. Sudheesh PS, LaFrentz BR, Call DR, Siems WF, LaPatra SE, et al. (2007) Identification of potential vaccine target antigens by immunoproteomic analysis of a virulent and a non-virulent strain of the fish pathogen Flavobacterium psychrophilum. Dis Aquat Org 74: 37-47.

120. Rasoli M, Omar AR, Aini I, Jalilian B, Syed Hassan SH, et al. (2010) Fusion of Hsp70 gene of Mycobacterium tuberculosis to hemagglutinin (H5) gene of avian influenza virus in DNA vaccine enhances its potency. Acta Virol 54 33-39.

121. Suzue K, Young RA (1996) Adjuvant-free hsp70 fusion protein system elicits humoral and cellular immune responses to HIV-1 p24. J Immunol 156: 873879 .

122. Gagné, Nellie. Novel recombinant vaccine models against Infectious Salmon Anemia Virus (ISA). 2009. 27 October 2011 